\title{
Gd3TCAS2: An Aquated Gd3+-Thiacalix[4]arene Sandwich Cluster with Extremely Slow Ligand Substitution Kinetics
}

\section{Citation}

Iki, Nobuhiko, Eszter Boros, Mami Nakamura, Ryo Baba, and Peter Caravan. 2016. “Gd3TCAS2: An Aquated Gd3+-Thiacalix[4]arene Sandwich Cluster with Extremely Slow Ligand Substitution Kinetics." Inorganic Chemistry 55 (8): 4000-4005. doi:10.1021/acs.inorgchem.6b00241. http:// dx.doi.org/10.1021/acs.inorgchem.6b00241.

\section{Published Version}

doi:10.1021/acs.inorgchem.6b00241

\section{Permanent link}

http://nrs.harvard.edu/urn-3:HUL.InstRepos:32072024

\section{Terms of Use}

This article was downloaded from Harvard University's DASH repository, and is made available under the terms and conditions applicable to Other Posted Material, as set forth at http:// nrs.harvard.edu/urn-3:HUL.InstRepos:dash.current.terms-of-use\#LAA

\section{Share Your Story}

The Harvard community has made this article openly available.

Please share how this access benefits you. Submit a story.

Accessibility 


\title{
$\mathrm{Gd}_{3} \mathrm{TCAS}_{2}$ : An Aquated $\mathrm{Gd}^{3+}$-Thiacalix[4]arene Sandwich Cluster with Extremely Slow Ligand Substitution Kinetics
}

\author{
Nobuhiko Iki, ${ }^{* \dagger}{ }^{\dagger}$ Eszter Boros, ${ }^{\ddagger}$ Mami Nakamura, ${ }^{\dagger}$ Ryo Baba, ${ }^{\dagger}$ and Peter Caravan ${ }^{*}{ }^{\ddagger}$ \\ ${ }^{\dagger}$ Graduate School of Environmental Studies, Tohoku University, 6-6-07 Aramaki-Aoba, Aoba-ku, Sendai 980-8579, Japan \\ ${ }^{\ddagger}$ A. A. Martinos Center for Biomedical Imaging, Massachusetts General Hospital, Harvard Medical School, 149 13th Street, Suite \\ 2301, Charlestown, Massachusetts 02129, United States
}

\section{Supporting Information}

ABSTRACT: In aqueous solution, $\mathrm{Gd}^{3+}$ and thiacalix[4] arene$p$-tetrasulfonate (TCAS) form the complex $\left[\mathrm{Gd}_{3} \mathrm{TCAS}_{2}\right]^{7-}$, in which a trinuclear $\mathrm{Gd}^{3+}$ core is sandwiched by two TCAS ligands. Acid-catalyzed dissociation reactions, as well as transmetalation and ligand exchange with physiological concentrations of $\mathrm{Zn}^{2+}$ and phosphate, showed $\left[\mathrm{Gd}_{3} \mathrm{TCAS}_{2}\right]^{7-}$ to be extremely inert compared to other $\mathrm{Gd}$ complexes. Luminescence lifetime measurements of the $\mathrm{Tb}$ analogue $\mathrm{Tb}_{3} \mathrm{TCAS}_{2}$ allowed estimation of the mean hydration number $q$ to be 2.4 per $\mathrm{Tb}$ ion. The longitudinal relaxivity of $\left[\mathrm{Gd}_{3} \mathrm{TCAS}_{2}\right]^{7-}\left(\right.$ per $\left.\mathrm{Gd}^{3+}\right)$ was $r_{1}=5.83 \mathrm{mM}^{-1} \mathrm{~s}^{-1}$ at $20 \mathrm{~Hz}$

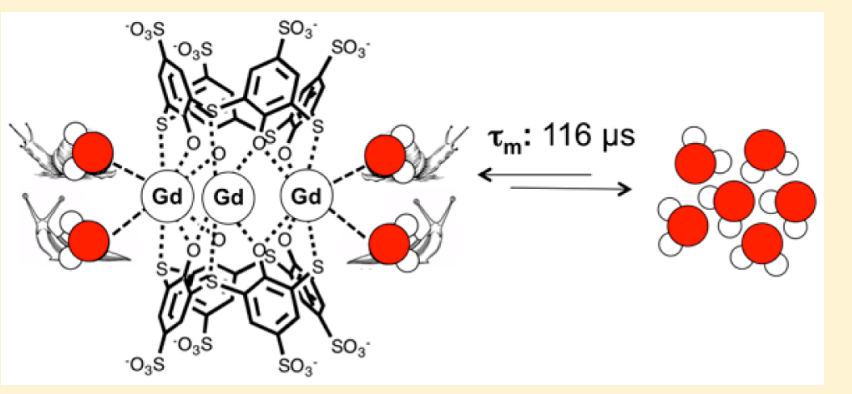
$\left(37^{\circ} \mathrm{C}, \mathrm{pH} 7.4\right)$; however, this relaxivity was limited by an extremely slow water exchange rate that was 5 orders of magnitude slower than the $\mathrm{Gd}^{3+}$ aqua ion. Binding to serum albumin resulted in no relaxivity increase owing to the extremely slow water exchange kinetics. The slow dissociation and water exchange kinetics of $\left[\mathrm{Gd}_{3} \mathrm{TCAS}_{2}\right]^{7-}$ can be attributed to the very rigid coordination geometry.

\section{INTRODUCTION}

The aqueous coordination chemistry of the trivalent lanthanides is characterized by high coordination numbers and, classically, kinetically labile complexes. For instance the aqua ion $\mathrm{Gd}^{3+}{ }_{(\mathrm{aq})}$ has the fastest water exchange rate of any trivalent metal ion $\left(1 \times 10^{9} \mathrm{~s}^{-1}\right.$ at $\left.25^{\circ} \mathrm{C}\right)$ and is at the extreme for water exchange among all metal ions in solution. ${ }^{1}$ The application of $\mathrm{Gd}(\mathrm{III})$ complexes as contrast agents in magnetic resonance imaging (MRI) led to a rich development in aqueous lanthanide coordination chemistry. ${ }^{2}$ Clinically approved contrast agents use octadentate polyaminocarboxylate ligands based on 1,4,7,10-tetraazacyclododecane-1,4,7,10-tetraacetic acid (DOTA) or diethylenetriamine pentaacetic acid (DTPA) to provide $\mathrm{Gd}(\mathrm{III})$ complexes safe for human use. ${ }^{3,4}$ These complexes also have one water coligand. The presence of the multidentate chelating ligand also affects the water exchange rate, and among these types of complexes, water exchange kinetics can be tuned over 5 orders of magnitude by judicious choice of the donor atoms on the multidentate ligand. 5,6

For $\mathrm{T}_{1}$ relaxation agents like $\mathrm{Gd}^{3+}$ complexes, the optimal water exchange rate is in the $1 \times 10^{7}$ to $1 \times 10^{8} \mathrm{~s}^{-1}$ range. $^{7}$ When the water exchange rate becomes too slow, the relaxivity of the complex is limited because the relaxed water molecule cannot exchange fast enough to diminish the relaxation time of bulk water. However, very slow water exchange can be exploited by using a non-Gd paramagnetic lanthanide ion that induces a large pseudocontact chemical shift. If the water exchange rate $(1 / \tau)$ is slow enough to meet the slow exchange condition $(\omega \tau>1)$, then the coordinated water ligand can be observed as a highly shifted ${ }^{1} \mathrm{H}$ NMR resonance. Saturation of this resonance results in transfer of saturation to the bulk water resonance resulting in MRI signal loss. This is the basis of paramagnetic chemical exchange saturation transfer (PARACEST) effect. ${ }^{8,9}$ For PARACEST applications the exchange rate should be from $1 \times 10^{3}$ to $1 \times 10^{4} \mathrm{~s}^{-1}$. For water exchange rates in the $1 \times 10^{5}$ to $1 \times 10^{6} \mathrm{~s}^{-1}$ range, there is another contrast generating effect called $\mathrm{T}_{2}$-exchange. ${ }^{10}$ This is essentially exchange broadening but by a highly shifted water ligand resonance. By judicious choice of lanthanide and coligand, different MRI contrast enhancing properties $\left(\mathrm{T}_{1}, \mathrm{~T}_{2}\right.$-exchange, saturation transfer) can be exploited. Thus, water exchange is a critical parameter to understand and control in lanthanide chemistry.

Almost all the ligand design in MR contrast agents has focused on DOTA and DTPA analogues because of their ability to form stable, inert complexes with $\mathrm{Ln}^{3+}$. Chelators of lower denticity fail to provide sufficient inertness for in vivo applications. Previously, we found that thiacalix[4]arene- $p$ tetrasulfonate (TCAS, Figure 1 ) is capable of binding $\mathrm{Ln}^{3+}$ ions in different binding modes depending on the reaction conditions and the species of countercation. ${ }^{11,12}$ For $\mathrm{Ln}=$ $\mathrm{Nd}$ and $\mathrm{Yb}$, we showed that it self-assembled to form a sandwich-type complex, $\left[\operatorname{Ln}_{3} \mathrm{TCAS}_{2}\right]^{7-}$, formed in which two

Received: February 5, 2016

Published: March 28, 2016 


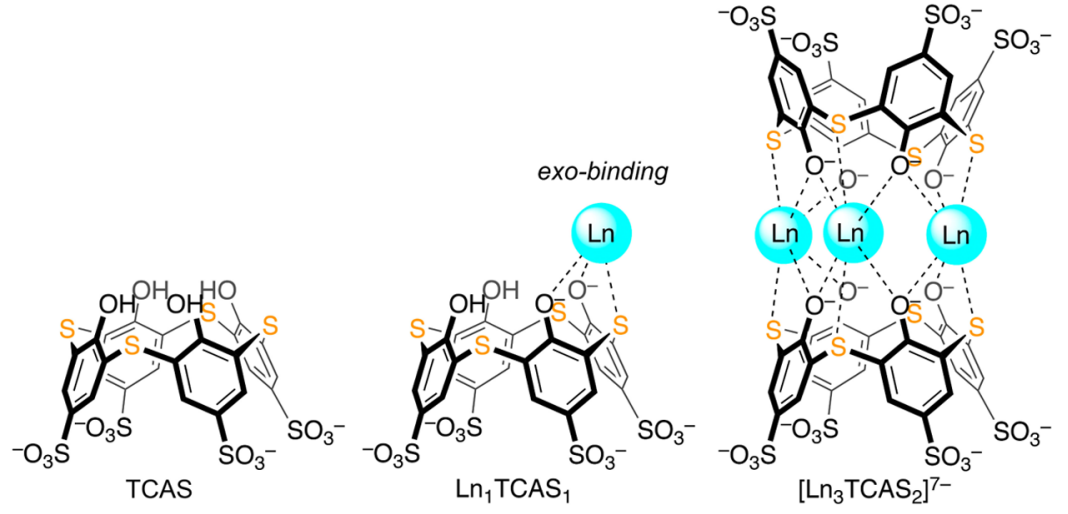

Figure 1. Structures of TCAS and the 1:1 and 3:2 lanthanide(III) complexes.
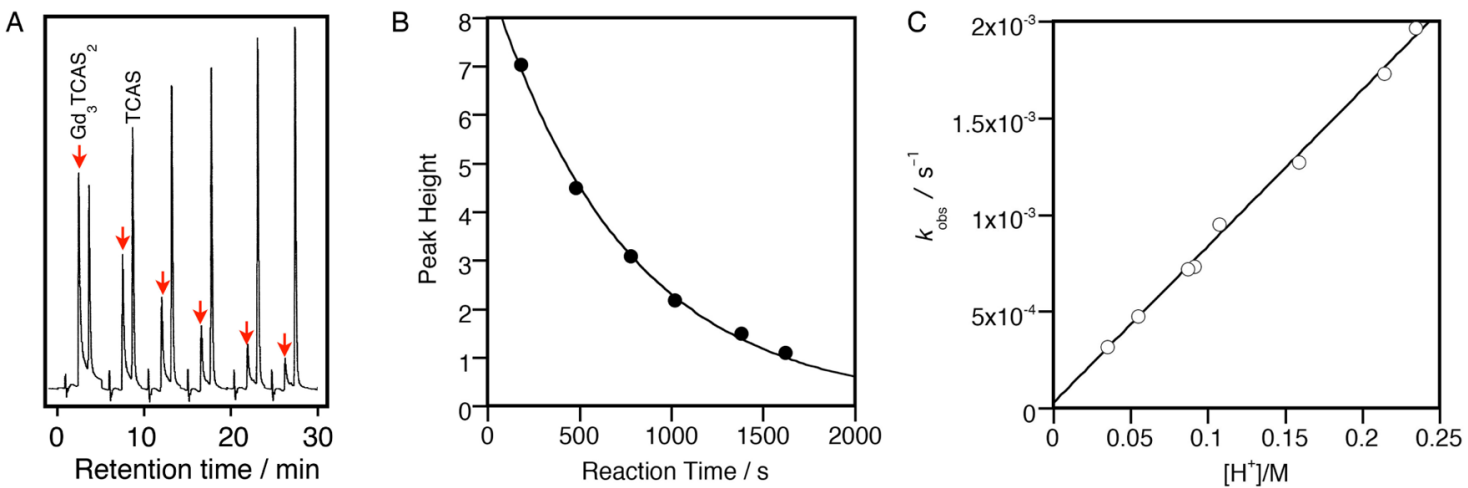

Figure 2. (A) Typical chromatograms of a reaction mixture of $\left[\mathrm{Gd}_{3} \mathrm{TCAS}_{2}\right]^{7-}$ under acid-catalyzed dissociation conditions, (B) time dependence of peak height $(H)$ of $\left[\mathrm{Gd}_{3} \mathrm{TCAS}_{2}\right]^{7-}$, and $(\mathrm{C})$ dependence of the observed dissociation rate constant, $k_{\mathrm{obs}}$, on proton concentration, $\left[\mathrm{H}^{+}\right]$at $25^{\circ} \mathrm{C}(I=$ $0.5 \mathrm{M})$. Sample: $[\mathrm{Gd}]=6.0 \times 10^{-5} \mathrm{M},[\mathrm{TCAS}]=4.0 \times 10^{-5} \mathrm{M},[\mathrm{HCl}]=0.15 \mathrm{M}, \mathrm{pH} 0.89, I=0.50 \mathrm{M}, 25^{\circ} \mathrm{C}$. (A) Eluent: $[\mathrm{HEPES}]=0.01 \mathrm{~mol} / \mathrm{kg}$ (pH 7.4), [TBABr] $=30 \mathrm{mmol} / \mathrm{kg}$ in $50 \mathrm{wt} \% \mathrm{CH}_{3} \mathrm{CN}$. Flow rate: $2 \mathrm{~mL} / \mathrm{min}$, injection volume: $5 \mu \mathrm{L}$, detection wavelength: $320 \mathrm{~nm}$. (B) The decay of $H$ was fitted with an equation: $H=A \exp \left(-1.27 \times 10^{-3} t\right)$ with $R^{2}=0.997$.

cone-shaped TCAS ligands sandwich a trinuclear $\mathrm{Ln}^{3+}$ core. ${ }^{13}$ The ligand binds to the metal ions at the periphery, which we refer to as an exo-binding mode. The $\mathrm{Yb}$ (III) complex exhibited remarkable kinetic inertness for dissociation in strong acid (half-life $t_{1 / 2}=1.53 \mathrm{~h}$ at $\mathrm{pH} 1.16,25{ }^{\circ} \mathrm{C}$ ), which was unexpected from the exo-binding mode. The mean hydration number per $\mathrm{Yb}(\mathrm{III})$ ion was $q=2.5$ in $\left[\mathrm{Yb}_{3} \mathrm{TCAS}_{2}\right]^{7-} \cdot{ }^{3}$ Given high kinetic inertness, the large hydration number, and the presence of three $\mathrm{Ln}^{3+}$ ions in a compact structure, we hypothesized that the corresponding $\mathrm{Gd}^{3+}$ analogue, $\left[\mathrm{Gd}_{3} \mathrm{TCAS}_{2}\right]^{7-}$, could be a promising candidate for development of high relaxivity Gd-based contrast agents. Instead we observed a remarkable inertness of water exchange that ultimately muted relaxivity.

\section{RESULTS AND DISCUSSION}

Preparation of $\mathbf{G d}_{3} \mathrm{TCAS}_{2}$. Previously, we formed $\left[\mathrm{Ln}_{3} \mathrm{TCAS}_{2}\right]^{7-}\left(\mathrm{Ln}^{3+}=\mathrm{Nd}^{3+}, \mathrm{Yb}^{3+}\right)$ in 24 h by self-assembly of the components at $\mathrm{pH} 7.4{ }^{13}$ We sought optimum conditions to scale up the reaction while avoiding the formation of unwanted impurities such as $\mathrm{Gd}_{2} \mathrm{TCAS}_{2}$ and $\mathrm{Gd}_{4} \mathrm{TCAS}_{2}$. We were able to obtain $1.31 \mathrm{~g}$ of a solid powder containing $\mathrm{Na}_{7}\left[\mathrm{Gd}_{3} \mathrm{TCAS}_{2}\right]\left(2.0 \times 10^{-4} \mathrm{~mol}\right)$ and CAPS $(2.5 \mathrm{mmol})$, the latter of which was used to buffer the $\mathrm{pH}$ to 11.2 for the initial complex formation. To confirm that other species $\mathrm{Gd}_{n} \mathrm{TCAS}_{2}$ $(n=2,4)$ were not formed, we analyzed the reaction mixture and the resultant powder by capillary electrophoresis (CE). CE is able to separate $\operatorname{Ln}_{n} \mathrm{TCAS}_{2}$ species $(n=2-4)$ with high resolution based on the charge-to-size ratio. The only obtained and detected species was $\left[\mathrm{Gd}_{3} \mathrm{TCAS}_{2}\right]^{7-}$ (Figure S1; see also Figure $\mathrm{S} 2$ for $\mathrm{Nd}, \mathrm{Tb}$, and $\mathrm{Yb}$ analogues).

Kinetic Inertness. A prerequisite for in vivo use is high kinetic inertness under physiological conditions. We determined the solvolytic dissociation rate constant $\left(k_{\mathrm{d}}\right)$ of $\left[\mathrm{Gd}_{3} \mathrm{TCAS}_{2}\right]^{7-}$ under acid-catalyzed conditions $\left(\left[\mathrm{H}^{+}\right]=\right.$ $0.03-0.23 \mathrm{M})$ at $25^{\circ} \mathrm{C}$. The dissociation of the $\left[\mathrm{Gd}_{3} \mathrm{TCAS}_{2}\right]^{7-}$ sandwich cluster was followed in the presence of excess acid to guarantee the pseudo-first-order condition. The reaction was monitored by HPLC to selectively detect the signal from the remaining $\left[\mathrm{Gd}_{3} \mathrm{TCAS}_{2}\right]^{7-}$ in the reaction mixture (Figure $2 \mathrm{~A}$ ). The time dependence of the peak height clearly showed a single exponential decay to give the observed dissociation rate constants $\left(k_{\text {obs }}\right.$; Figure $\left.2 \mathrm{~B}\right)$. This reaction was studied at different acid concentrations while keeping the ionic strength constant $(I=0.5 \mathrm{M})$ to afford first-order dependence of $k_{\mathrm{obs}}$ on $\left[\mathrm{H}^{+}\right]$(Figure 2C, eq 1).

$$
k_{\mathrm{obs}}=k_{\mathrm{d}}+k^{\mathrm{H}}\left[\mathrm{H}^{+}\right]
$$

This suggests that there are two paths of dissociation: solvolytic dissociation and proton-assisted. In the latter, a protonated species, $\left[\mathrm{Gd}_{3} \mathrm{H}_{1} \mathrm{TCAS}_{2}\right]^{6-}$, dissociates with a second-order rate constant $k^{\mathrm{H}}$. The protonation likely occurs on one of the phenolic oxygens of TCAS, which in turn should decrease the donating ability to $\mathrm{Gd}^{3+}$ and increase dissociation of the $\mathrm{Gd}^{3+}$ ion. By fitting with eq 1 , both of the rate constants were estimated: $k_{\mathrm{d}}=(2.73 \pm 2.67) \times 10^{-5} \mathrm{~s}^{-1}$ and $k^{\mathrm{H}}=(8.10 \pm$ 

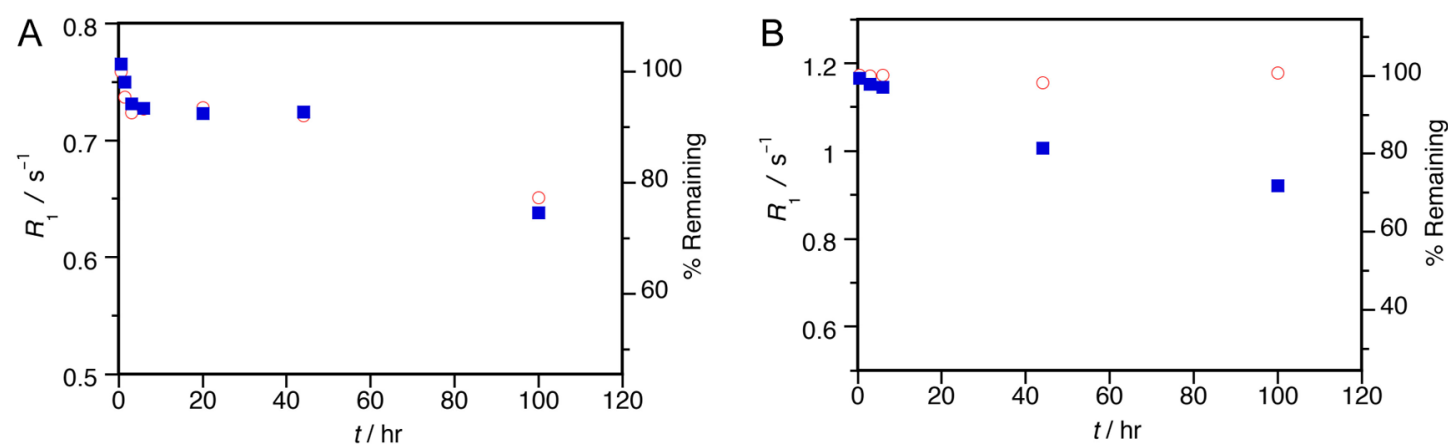

Figure 3. Time dependence of the longitudinal relaxation rate $R_{1}$ of solutions containing (A) $\left[\mathrm{Gd}_{3} \mathrm{TCAS}_{2}\right]^{7-}$ and (B) MS-325 in the presence or absence of $\mathrm{Zn}^{\mathrm{II}}$ ion. Reaction conditions: $[\mathrm{Gd}]_{\text {total }}=0.1 \mathrm{mM},\left[\mathrm{Zn}(\mathrm{OTf})_{2}\right]=0$ (o) or $0.1 \mathrm{mM}(\boldsymbol{\square})$, [phosphate $]=1.0 \mathrm{M}, \mathrm{pH} 7.0,25^{\circ} \mathrm{C}$. Relaxivity measurement: $37^{\circ} \mathrm{C}, 60 \mathrm{MHz}$.

$0.19) \times 10^{-3} \mathrm{M}^{-1} \mathrm{~s}^{-1}$. The large uncertainty associated with $k_{\mathrm{d}}$ stems from the fact the dominant path of dissociation is the proton-assisted path via $\left[\mathrm{Gd}_{3} \mathrm{H}_{1} \mathrm{TCAS}_{2}\right]^{6-}$ under the conditions studied. $\left[\mathrm{Gd}_{3} \mathrm{TCAS}_{2}\right]^{7-}$ exhibits a remarkable kinetic inertness with a $t_{1 / 2}=2.4 \mathrm{~h}$ at $\mathrm{pH}$ 2. The dissociation kinetics of $\left[\mathrm{Gd}_{3} \mathrm{TCAS}_{2}\right]^{7-}$ can be compared to approved contrast agents where its inertness appears intermediate between acyclic contrast agents and macrocyclic agents. The proton-assisted dissociation rate constant $k^{\mathrm{H}}$ is 3 times larger than for [Gd(HPDO3A) $]\left(2.9 \times 10^{-4} \mathrm{M}^{-1} \mathrm{~s}^{-1}\right),{ }^{14}$ but 2 orders of magnitude smaller than for $[\mathrm{Gd}(\mathrm{DTPA})]^{2-}\left(0.58 \mathrm{M}^{-1} \mathrm{~s}^{-1}\right){ }^{15}$

We also assessed kinetic inertness under more physiological conditions. In the body, endogenous ions such as $\mathrm{Zn}^{2+}$ and phosphate can catalyze transchelation of the $\mathrm{Gd}^{3+}$ complex (GdL), leading to dissociation via transmetalation (to $\mathrm{ZnL}$ ) and ligand substitution (to $\mathrm{GdPO}_{4}$ ). We used a standard assay ${ }^{16}$ to monitor changes in the longitudinal nuclear relaxation rate $R_{1}$ $\left(=1 / T_{1}\right)$ of solvent water for $\left[\mathrm{Gd}_{3} \mathrm{TCAS}_{2}\right]^{7-}$ in the presence of $1.0 \mathrm{M}$ phosphate and $0.1 \mathrm{mM} \mathrm{Zn}{ }^{2+}$. $\mathrm{GdPO}_{4}$ precipitates out of the solution upon formation resulting in a decrease in $R_{1}$. In the absence of $\mathrm{Zn}^{2+}$, the $R_{1}$ value showed a $5 \%$ decrease in the first $3 \mathrm{~h}$, a plateau until $44 \mathrm{~h}$, then a $23 \%$ decrease at $100 \mathrm{~h}$ (Figure $3 \mathrm{Ao}$ ). The initial rapid decrease in $R_{1}$ may be attributed to an initial ternary phosphate complex while the slower decrease in $R_{1}$ is caused by the dissociation of $\left[\mathrm{Gd}_{3} \mathrm{TCAS}_{2}\right]^{7-}$ to form $\mathrm{GdPO}_{4}$. Notably, even after $100 \mathrm{~h} 77 \%$ of $\left[\mathrm{Gd}_{3} \mathrm{TCAS}_{2}\right]^{7-}$ remained intact (for estimation, see Supporting Information). This clearly indicates that $\left[\mathrm{Gd}_{3} \mathrm{TCAS}_{2}\right]^{7-}$ is substantially inert at neutral $\mathrm{pH}$. In the presence of $\mathrm{Zn}^{2+}$, the behavior of $R_{1}$ over time (Figure 3A ) was comparable to $R_{1}$ measured in the absence of $\mathrm{Zn}^{2+}$, suggesting that any dissociation proceeds not by transmetalation, but rather by ligand substitution with phosphate. This is evident when $R_{1}$ with $\mathrm{Zn}^{2+}$ is standardized by $R_{1}$ without $\mathrm{Zn}^{2+}$. $\left[\mathrm{Gd}_{3} \mathrm{TCAS}_{2}\right]^{7-}$ did not show a significant change until $45 \mathrm{~h}$ and only a slight decrease after $100 \mathrm{~h}$, suggesting $\left[\mathrm{Gd}_{3} \mathrm{TCAS}_{2}\right]^{7-}$ is not sensitive to transmetalation by $\mathrm{Zn}^{2+}$ (Figure 4).

For comparison, we also measured the time course of $R_{1}$ for the Food and Drug Administration approved contrast agent MS-325 (gadofosveset, Ablavar) in the same fashion. ${ }^{17,18}$ Of the approved linear contrast agents (Gd-DTPA, etc), MS-325 was the most inert in this assay. ${ }^{19}$ In the absence of $\mathrm{Zn}^{2+}$, little change of $R_{1}$ value was observed even at $t=100 \mathrm{~h}$ (Figure $3 \mathrm{Bo})$, suggesting that MS-325 is very inert to ligand substitution by phosphate. However, in the presence of $\mathrm{Zn}^{2+}$, the $R_{1}$ value gradually decreased (Figure 3B $\square$ ) indicating a more facile transmetalation than observed for $\left[\mathrm{Gd}_{3} \mathrm{TCAS}_{2}\right]^{7-}$

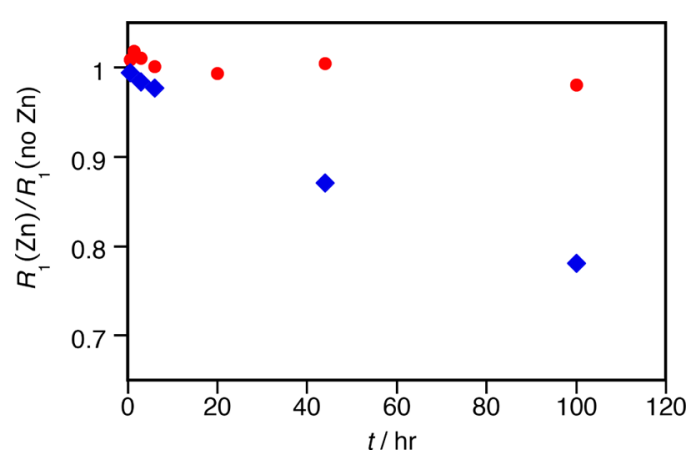

Figure 4. Time dependence of the longitudinal relaxation rate $R_{1}(\mathrm{Zn})$ of solutions containing $(\bullet)\left[\mathrm{Gd}_{3} \mathrm{TCAS}_{2}\right]^{7-}$ and $(\bullet)$ MS-325 in the presence of $\mathrm{Zn}^{\mathrm{II}}$ ion standardized to the relaxation rate measured in the absence of $\mathrm{Zn}^{\mathrm{II}}, R_{1}$ (no $\mathrm{Zn}$ ). Reaction conditions: $\left[\mathrm{Gd}^{3+}\right]_{\text {total }}=0.1$ $\mathrm{mM},\left[\mathrm{Zn}(\mathrm{OTf})_{2}\right]=0$ or $0.1 \mathrm{mM}$, [phosphate $]=1.0 \mathrm{M}, \mathrm{pH} 7,25^{\circ} \mathrm{C}$. Relaxivity measurement: $37^{\circ} \mathrm{C}, 60 \mathrm{MHz}$.

(Figure 3A ). This is further seen in Figure 4 when $R_{1}$ with $\mathrm{Zn}^{2+}$ is standardized by $R_{1}$ without $\mathrm{Zn}^{2+}$ and indicates that MS325 dissociation proceeds by exchange of $\mathrm{Gd}^{3+}$ with $\mathrm{Zn}^{2+}$. $\left[\mathrm{Gd}_{3} \mathrm{TCAS}_{2}\right]^{7-}$ is very inert under both highly forcing, acidic conditions as well as under excess $\mathrm{Zn}^{2+}$ and phosphate challenge, suggesting sufficient kinetic inertness for in vivo applications.

Determination of Hydration Number of $\left[\mathrm{Tb}_{3} \mathrm{TCAS}_{2}\right]^{7-}$. As a surrogate for $\left[\mathrm{Gd}_{3} \mathrm{TCAS}_{2}\right]^{7-}$, we used the luminescent $\left[\mathrm{Tb}_{3} \mathrm{TCAS}_{2}\right]^{7-}$ complex, which we anticipate is isostructural based on the similar ionic radii of $\mathrm{Gd}^{3+}$ and $\mathrm{Tb}^{3+}$. Here the $\mathrm{Tb}^{3+}$-centered luminescence lifetime was measured in $\mathrm{H}_{2} \mathrm{O}$ and $\mathrm{D}_{2} \mathrm{O}\left(\tau_{\mathrm{H}}\right.$ and $\tau_{\mathrm{D}}$, respectively), and $q$ was estimated using Horrocks' equation. ${ }^{20,21}$ We estimate an average $q$ value of 2.4 per ion (Table S2 Supporting Information). This could indicate two $\mathrm{Tb}$ (III) ions with two water ligands and the third ion with three water ligands, and it strongly suggests that each $\mathrm{Gd}$ in $\left[\mathrm{Gd}_{3} \mathrm{TCAS}_{2}\right]^{7-}$ is $q \geq 2$.

Water Exchange Kinetics. We evaluated the mean water exchange kinetics at each $\mathrm{Gd}^{3+}$ center of $\left[\mathrm{Gd}_{3} \mathrm{TCAS}_{2}\right]^{7-}$ by measuring the ${ }^{17} \mathrm{O}$ NMR transverse relaxation rate $\left(R_{2}\right)$ of solvent water as a function of temperature in the presence $\left(R_{2}\right)$ and absence $\left(R_{2 \mathrm{~d}}\right)$ of $\left[\mathrm{Gd}_{3} \mathrm{TCAS}_{2}\right]^{7-}$. Normalizing the difference in these rates to the mole fraction of water that is coordinated to the Gd ion (we assumed $q=2$ ) gives the socalled reduced relaxation rate $R_{2 r}$. Figure 5 shows the temperature dependence of $\ln \left(R_{2 \mathrm{r}}\right)$ versus reciprocal temperature for $\left[\mathrm{Gd}_{3} \mathrm{TCAS}_{2}\right]^{7-}$. For most $\mathrm{Gd}^{3+}$ complexes, $R_{2 \mathrm{r}}$ 


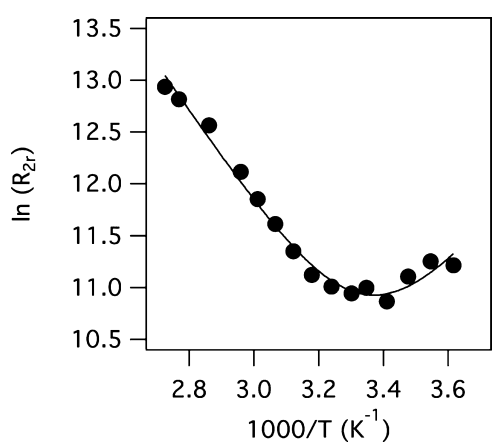

Figure 5. Temperature dependence of reduced ${ }^{17} \mathrm{O}$ transverse relaxation rate for $\left[\mathrm{Gd}_{3} \mathrm{TCAS}_{2}\right]^{7-}$ at $11.7 \mathrm{~T}$. Samples: $\left[\mathrm{Gd}_{3} \mathrm{TCAS}_{2}\right]^{7-}$ $=7.03 \mathrm{mM},[$ HEPES $]=50 \mathrm{mM}, \mathrm{pH}=7.4$. Temp: $3-94{ }^{\circ} \mathrm{C}$.

increases with increasing temperature, reaches a maximum and then decreases. However, for $\left[\mathrm{Gd}_{3} \mathrm{TCAS}_{2}\right]^{7-}$ we see $R_{2 \mathrm{r}}$ first decrease, reach a minimum at $\sim 25{ }^{\circ} \mathrm{C}$, and then increase as temperature is increased. This behavior is indicative of extremely slow water exchange.

For $\mathrm{Gd}^{3+}$ where the paramagnetic induced chemical shift is small compared to the $T_{2}$ of the coordinated water ligand $\left(T_{2 \mathrm{~m}}\right), R_{2 \mathrm{r}}$ depends on $T_{2 \mathrm{~m}}$ and the water residency time $\left(\tau_{\mathrm{m}}\right.$ reciprocal of water exchange rate, $\left.k_{\mathrm{ex}}\right)$ as described by eq $2:^{22}$

$$
R_{2 \mathrm{r}}=1 /\left(T_{2 \mathrm{~m}}+\tau_{\mathrm{m}}\right)+R_{2 \mathrm{OS}}
$$

The term $R_{2}$ os refers to paramagnetic relaxation of water outside the first coordination sphere, and for most Gd(III) complexes this term makes a negligible contribution to $R_{2 \mathrm{r}}$. In the slow exchange regime $\left(\tau_{\mathrm{m}} \gg T_{2 \mathrm{~m}}\right)$, the reduced relaxation rate simplifies to eq 3 .

$$
R_{2 \mathrm{r}}=1 / \tau_{\mathrm{m}}+R_{2 \mathrm{OS}}
$$

This is the behavior that we observe for $\left[\mathrm{Gd}_{3} \mathrm{TCAS}_{2}\right]^{7-}$. As the temperature is lowered, the $\tau_{\mathrm{m}}$ increases with respect to $R_{2} \mathrm{OS}$ and eventually results in $R_{2 \mathrm{r}}=R_{2 \mathrm{OS}}$. Generally, for $\mathrm{Gd}^{3+}$ the $R_{20 S}$ term is much smaller than the contribution from innersphere water and can be ignored, ${ }^{23}$ but for $\left[\mathrm{Gd}_{3} \mathrm{TCAS}_{2}\right]^{7-}, \tau_{\mathrm{m}}$ is so long at low temperatures that this outer-sphere phenomenon becomes observable. A similar outer-sphere effect on $R_{2 \mathrm{r}}$ has been reported for the solvent exchange of the complex $\left[\mathrm{Ti}(\mathrm{DMF})_{6}\right]^{3+} \cdot 24$

We calculated the $\tau_{\mathrm{m}}$ of the coordinated waters to be $116 \mu \mathrm{s}$ at $25{ }^{\circ} \mathrm{C}$ (or $20.8 \mu \mathrm{s}$ at $37^{\circ} \mathrm{C}$, see Supporting Information). As a comparison, $\tau_{\mathrm{m}}$ of the aqua ion $\left[\mathrm{Gd}\left(\mathrm{H}_{2} \mathrm{O}\right)_{9}\right]^{3+}$ is 5 orders of magnitude shorter $\left(0.9 \mathrm{~ns}\right.$ at $\left.25^{\circ} \mathrm{C}\right) .{ }^{25}$ Only the $\mathrm{Gd}^{3+}$ complex of the tetra(methylphosphonate)amide derivative of DOTA, $\left[\mathrm{Gd}(\mathrm{DOTA}-4 \mathrm{AMP})\left(\mathrm{H}_{2} \mathrm{O}\right)\right]^{5-}$, has a longer reported $\tau_{\mathrm{m}}{ }^{26}$ The extremely slow water exchange rate suggests that the proton relaxivity will be very low.

An alternative model is that there are two classes of coordinated water ligands. There is obviously a very slow exchangeable water, but the magnitude of the $R_{2}$ os term is compatible with an extremely fast exchangeable water; for example, $R_{2}$ os observed here is comparable to $R_{2 \mathrm{r}}$ for $\left[\mathrm{Gd}\left(\mathrm{H}_{2} \mathrm{O}\right)_{8}\right]^{3+}$ at the same temperature. ${ }^{27}$ Using this physical model, we assumed that for the $\left[\mathrm{Gd}_{3} \mathrm{TCAS}_{2}\right]^{7-}$ cluster that there were two slow exchangeable water molecules per $\mathrm{Gd}$ and one fast exchangeable water per cluster (since the $\mathrm{Tb}$ luminescence gave $q=7$ per cluster). This model will also fit the data in Figure 5 equally well since essentially we are replacing the $R_{2}$ os term in eq 3 with a $1 / T_{2 \mathrm{~m}}$ fast term (the $T_{2}$ of the coordinated rapidly exchanging water). In that model, the residency time of the fast exchanging water is $0.6 \mathrm{~ns}$ at $37^{\circ} \mathrm{C}$. We have no way of knowing the relative population of very fast and very slow exchangeable water molecules, but if we arbitrarily take a different model with five slow exchanging waters and two fast exchanging waters, then the residence time of the slow exchanging waters decreases from 17 to $14 \mu \mathrm{s}$ at 37 ${ }^{\circ} \mathrm{C}$, and the fast exchanging water residency times change from 0.6 to 0.3 ns. Regardless, there would exist two classes of exchangeable water molecules separated by over 4 orders of magnitude.

Proton Relaxivity. Relaxivity, $r_{1}$, per Gd was determined in 4-(2-hydroxyethyl)piperazine-1-ethanesulfonic acid (HEPES) buffer and in excess human serum albumin (HSA) at 0.47 and $1.41 \mathrm{~T}$, Table 1 . We independently measured the affinity of

Table 1. Per Gd Relaxivity and Estimated $T_{1 \mathrm{~m}}$ Values $^{a}$ (at $1.4 \mathrm{~T})$ for $\left[\mathrm{Gd}_{3} \mathrm{TCAS}_{2}\right]^{7-}$

$\begin{array}{lccc} & \begin{array}{c}r_{1}(0.47 \mathrm{~T}) \\ {\left[\mathrm{mM}^{-1} \mathrm{~s}^{-1}\right]}\end{array} & \begin{array}{c}r_{1}(1.41 \mathrm{~T}) \\ {\left[\mathrm{mM}^{-1} \mathrm{~s}^{-1}\right]}\end{array} & \begin{array}{c}T_{1 \mathrm{~m}} \\ {[\mu \mathrm{s}]}\end{array} \\ {\left[\mathrm{Gd}_{3} \mathrm{TCAS}_{2}\right]^{7-}} & 5.8 & 7.0 & 2.3 \\ {\left[\mathrm{Gd}_{3} \mathrm{TCAS}_{2}\right]^{7-} \text { in }} & 5.5 & 6.1 & 0.8\end{array}$

HSA

${ }^{a}$ In presence and absence of HSA at $37^{\circ} \mathrm{C}$ measured at $[\mathrm{Gd}]<0.15$ mM. $\tau_{\mathrm{m}}$ from ${ }^{17} \mathrm{O} \mathrm{NMR}$ is $21 \mu \mathrm{s}$ at $37{ }^{\circ} \mathrm{C}$, and thus $\tau_{\mathrm{m}} \gg T_{1 \mathrm{~m}}$.

$\left[\mathrm{Tb}_{3} \mathrm{TCAS}_{2}\right]^{7-}$ for HSA $\left(K_{\mathrm{b}}=(1.71 \pm 0.31) \times 10^{6} \mathrm{M}^{-1}, 20\right.$ $\mathrm{mM}$ HEPES, $\mathrm{pH} 7.4,25{ }^{\circ} \mathrm{C}$, see Supporting Information, section 5), and a hydration number of $q=1.7$ for the HSAbound complex. Because of its high affinity for HSA, $\left[\mathrm{Gd}_{3} \mathrm{TCAS}_{2}\right]^{7-}$ is effectively completely bound to albumin for these measurements. The measured relaxivity values in Table 1 are in line with the very slow water exchange kinetics. Equation 4 relates the contribution to relaxivity due to the inner-sphere water ligands.

$$
r_{1}^{\mathrm{IS}}=\left(q /\left[\mathrm{H}_{2} \mathrm{O}\right]\right) /\left(\mathrm{T}_{1 \mathrm{~m}}+\tau_{\mathrm{m}}\right)
$$

From the Solomon-Bloembergen-Morgan equation, one can estimate $T_{1 \mathrm{~m}}$ for $\left[\mathrm{Gd}_{3} \mathrm{TCAS}_{2}\right]^{7-}$ in the absence and presence of HSA, assuming rotational correlation times of $250 \mathrm{ps}$ and 10 $\mathrm{ns},{ }^{6,28}$ respectively (Table 1 ). Relaxivity in both cases is almost exclusively determined by $\tau_{\mathrm{m}}$ even at $37{ }^{\circ} \mathrm{C}$. The contribution to relaxivity from the 2.5 water ligands is only $1.9 \mathrm{mM}^{-1} \mathrm{~s}^{-1}$ at $37^{\circ} \mathrm{C}$ and less as temperature is decreased. In HSA solution the inner-sphere water ligands only contribute $2.1 \mathrm{mM}^{-1} \mathrm{~s}^{-1}$ to the observed relaxivity. This slight decrease in relaxivity compared to the unbound state is at odds with other HSA-bound complexes $^{29}$ but consistent with the extremely slow water exchange rate and the reduced hydration number from 2.5 to 1.7 upon HSA binding. Interestingly, if the water exchange rate was 1000 -fold faster (typical of many Gd complexes), then the relaxivity would be in excess of $150 \mathrm{mM}^{-1} \mathrm{~s}^{-1}$ at $0.47 \mathrm{~T}$ and $>50 \mathrm{mM}^{-1} \mathrm{~s}^{-1}$ at $1.4 \mathrm{~T}$. The extremely slow water exchange rate has effectively quenched the relaxivity. We also made measurements at lower temperatures, and the relaxivity increased slightly to $7.9 \mathrm{mM}^{-1} \mathrm{~s}^{-1}$ at $13{ }^{\circ} \mathrm{C}$ (see Supporting Information); cooling will further decrease $r_{1}{ }^{\text {IS }}$ but will increase the second/outer-sphere relaxivity.

We also studied the effect of concentration on relaxivity. For a single species in solution, a plot of the longitudinal relaxation rate, $R_{1}\left(=1 / T_{1}\right)$ as a function of $[\mathrm{Gd}]\left(=3\left[\mathrm{Gd}_{3} \mathrm{TCAS}_{2}\right]^{7-}\right)$ should give a straight line with the slope giving the relaxivity. 
However, for $\left[\mathrm{Gd}_{3} \mathrm{TCAS}_{2}\right]^{7-}$ we observed nonlinear behavior with the slope decreasing at concentrations above $[\mathrm{Gd}]=0.4$ $\mathrm{mM}$. This concentration-dependent behavior suggested the aggregation of $\left[\mathrm{Gd}_{3} \mathrm{TCAS}_{2}\right]^{7-}$ at higher concentrations. We were able to confirm the presence of aggregation by dynamic light scattering (DLS) measurements of different concentrations of $\left[\mathrm{Gd}_{3} \mathrm{TCAS}_{2}\right]^{7-}([\mathrm{Gd}]=0.1-2.0 \mathrm{mM})$. DLS showed an increase in mean diameter from 0.7 to $10 \mathrm{~nm}$ at $[\mathrm{Gd}]=0.4$ $\mathrm{mM}$ (Figure 5), implying the formation of an aggregate above this concentration. Hence, the data in the low concentration range $(0-0.15 \mathrm{mM})$, showing good linearity (Figure S7B), was used for determination of $r_{1}$ reported in Table 1 . The reduction in relaxivity at higher concentrations suggests a reduction of water access (reduced $q$ ) in the aggregate as was seen in the HSA-bound species. The $\mathrm{Tb}$ luminescence measurements were performed at low micromolar concentration, and the hydration state reflects the monomeric $\left[\mathrm{Gd}_{3} \mathrm{TCAS}_{2}\right]^{7-}$ species.

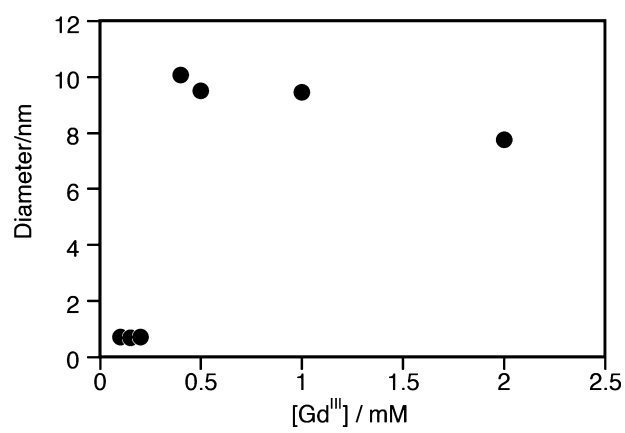

Figure 6. Dependence of number mean diameter on the concentration of Gd. Sample: [Gd] $\left(=3\left[\mathrm{Gd}_{3} \mathrm{TCAS}_{2}\right]^{7-}\right)=0.1-2 \mathrm{mM}$, [HEPES $]=$ $50 \mathrm{mM}, \mathrm{pH}=7.4$ at $25{ }^{\circ} \mathrm{C}$.

Only very few Gd complexes can be found in literature that show similarity to $\left[\mathrm{Gd}_{3} \mathrm{TCAS}_{2}\right]^{7-}$. Among the few is the structurally similar $\left[\mathrm{Gd}_{3}\left(\mathrm{H}_{3} \mathrm{taci}\right)_{2}\left(\mathrm{H}_{2} \mathrm{O}\right)_{6}\right]^{3+}$ complex, which was reported to have a much shorter mean water residency time, with $91 \mathrm{~ns}$ at $25{ }^{\circ} \mathrm{C} .{ }^{30}$ This complex however was reported to be quite kinetically labile. The opposite is true for $\left[\mathrm{Gd}_{3} \mathrm{TCAS}_{2}\right]^{7-}$; the rigidity of the $\left[\mathrm{Gd}_{3} \mathrm{TCAS}_{2}\right]^{7-}$ system may make the nine-coordinated $\mathrm{Gd}^{3+}$ transition state energetically unfavorable. This results in slow water exchange, but it also rationalizes the kinetic inertness of $\left[\mathrm{Gd}_{3} \mathrm{TCAS}_{2}\right]^{7-}$ to solvolysis. Thus, the rigid structure of $\left[\mathrm{Gd}_{3} \mathrm{TCAS}_{2}\right]^{7-}$ has brought both preferable and negative consequences to its ability to act as a contrast agent: very high kinetic inertness yet extremely slow water exchange rate, limiting relaxivity.

In conclusion, we found that the unusual sandwich-cluster complex $\left[\mathrm{Gd}_{3} \mathrm{TCAS}_{2}\right]^{7-}$ has high kinetic inertness, high hydration number $(q \geq 2$ per Gd) as well as a high affinity to HSA: all prerequisites for MRI contrast agents. The relaxivity of the complex however was found to be much lower than expected both in the presence and absence of HSA, and this was due to an exceedingly slow water exchange rate. Indeed the extreme inertness of $\left[\mathrm{Gd}_{3} \mathrm{TCAS}_{2}\right]^{7-}$ with respect to dissociation and water exchange is akin to that seen with the $\operatorname{Ln}(\mathrm{III})$ complexes of DOTA-tetraamides. The slow water exchange kinetics of LnDOTA-tetraamide complexes (where $\mathrm{Ln} \neq \mathrm{Gd}$ ) have been exploited for PARACEST applications. ${ }^{88,31}$ Future investigations of the $\mathrm{Ln}_{3} \mathrm{TCAS}_{2}$ system will aim to exploit this slow water exchange rate for PARACEST applications.

\section{EXPERIMENTAL SECTION}

Equipment. A capillary electrophoresis measuring system CAPI3300 of Otsuka Electronics Co, Ltd. (Osaka) with a fused silica capillary $(50 \mu \mathrm{m}$ id) purchased from GL Sciences Inc. (Tokyo) was used to assess the purity of the prepared $\left[\mathrm{Gd}_{3} \mathrm{TCAS}_{2}\right]^{7-}$. The luminescent spectra in the visible region and the luminescence lifetimes were measured using a Hitachi F-4500 fluorescent spectrometer. An HPLC consisting of a Shimadzu LC-10AD pump and a JASCO UV 2075 Plus spectrophotometric detector equipped with a Mightysil ODS RP-18 GP II column $(150 \times 4.6 \mathrm{~mm}, 5 \mu \mathrm{m}$, Kanto Chemical Co, Inc.) was used. The chromatograms were recorded with a JASCO 807-IT integrator. Longitudinal relaxation times, $T_{1}$, were measured by using the inversion recovery method on Bruker Minispecs mq20 $(20 \mathrm{MHz})$ and mq60 $(60 \mathrm{MHz})$. Relaxivity was determined from the slope of a plot of $1 / T_{1}$ versus concentration for $\mathrm{Gd}^{\mathrm{III}}$. The $\mathrm{Gd}^{\mathrm{III}}$ concentrations of the measured samples were determined by inductively coupled plasma mass spectrometry on an Agilent 7500a system. Dynamic light scattering equipment Zetasizer Nano ZetasizerSP (Malvern Instruments Ltd, U.K) was used to estimate the size of aggregate of $\left[\mathrm{Gd}_{3} \mathrm{TCAS}_{2}\right]^{7-}$ observed at high concentration. ${ }^{17} \mathrm{O}$ NMR measurements of solutions were performed at $11.7 \mathrm{~T}$ on $150 \mu \mathrm{L}$ samples contained in $2 \mathrm{~mm}$ Shigemi tubes inside a $5 \mathrm{~mm}$ standard NMR tube on a Varian spectrometer. The $\mathrm{pH}$ was recorded using a TOA HM-25R $\mathrm{pH}$ meter with a combined glass electrode.

The TCAS was synthesized as previously reported ${ }^{[\mathrm{i}]}$ and stocked as an aqueous solution of $0.01 \mathrm{M}$. The stock solution of $0.01 \mathrm{M} \mathrm{Ln}^{\mathrm{III}}$ was prepared by dissolving nitrate hexahydrate ( $99.5 \%$ purity each) purchased from Wako Pure Chemical Industries, Ltd. (Osaka) into $0.01 \mathrm{M} \mathrm{HNO}_{3}$ solution. A stock solution of $0.01 \mathrm{M} \mathrm{Ag}^{\mathrm{I}}$ was prepared by dissolving $\mathrm{AgNO}_{3}$ (99.8\%, Kanto Chemical Company, Inc, Tokyo) in $0.01 \mathrm{M} \mathrm{HNO}_{3}$. The concentration of the metal ion in the stock solutions was determined using accepted chelatometry. ${ }^{[i i]} \mathrm{pH}$ buffers HEPES and $N$-cyclohexyl-3-aminopropane-sulfonic acid (CAPS) were purchased from Dojindo Laboratories, Kumamoto. All other chemicals used were of guaranteed ultrapure grade. Deionized water was used throughout the study.

Preparation of $\left[\mathrm{Gd}_{3} \mathrm{TCAS}_{2}\right]^{7-}$. To a $100 \mathrm{~mL}$ beaker, $0.5 \mathrm{M}$ CAPS buffer ( $\mathrm{pH} 11.2,5 \mathrm{~mL}), 24.6 \mathrm{mM}$ TCAS solution $(16.3 \mathrm{~mL})$, water (ca. $3 \mathrm{~mL}$ ), and $9.64 \mathrm{mM} \mathrm{Gd}\left(\mathrm{NO}_{3}\right)_{3}(62.2 \mathrm{~mL})$ were added. The $\mathrm{pH}$ of the mixture was adjusted to 11.2 by stepwise addition of $2 \mathrm{M} \mathrm{NaOH}$ in small portions. Then the solution was diluted to $100 \mathrm{~mL}$ with water $\left([\mathrm{Gd}]=3.0 \times 10^{-4} \mathrm{M},[\mathrm{TCAS}]=2.0 \times 10^{-4} \mathrm{M},[\mathrm{CAPS}]=2.0 \times 10^{-2}\right.$ $\mathrm{M}, \mathrm{pH} 11.2$ ). The reaction mixture stirred gently at $60{ }^{\circ} \mathrm{C}$ for $64.5 \mathrm{~h}$. Finally, the solution was evaporated to dryness at $45^{\circ} \mathrm{C}$, dried in vacuo at $45^{\circ} \mathrm{C}$ for $10 \mathrm{~h}$, and additionally dried in vacuo for $44 \mathrm{~h}$ over $\mathrm{P}_{2} \mathrm{O}_{5}$ to give $1.31 \mathrm{~g}$ of white powder of a mixture of sodium salts of $\left[\mathrm{Gd}_{3} \mathrm{TCAS}_{2}\right]^{7-}\left(2.0 \times 10^{-4} \mathrm{~mol}\right)$ and CAPS $(2.5 \mathrm{mmol})$. The reaction mixture after $1.0 \mathrm{~h}$ and the resulting solid powder were assayed with capillary electrophoresis (CE, Figure S1) to display essentially a single peak assigned to $\left[\mathrm{Gd}_{3} \mathrm{TCAS}_{2}\right]^{7-}$ that excluded formation of Gd-TCAS complexes of other stoichiometry.

\section{ASSOCIATED CONTENT}

\section{S Supporting Information}

The Supporting Information is available free of charge on the ACS Publications website at DOI: 10.1021/acs.inorgchem.6b00241.

Preparation of $\mathrm{Gd}_{3} \mathrm{TCAS}_{2}$, dissociation kinetics, determination of hydration number, binding of $\mathrm{Tb}_{3} \mathrm{TCAS}_{2}$ to HSA, longitudinal relaxation rates for $\mathrm{Gd}_{3} \mathrm{TCAS}_{2}$, temperature dependence of relaxivity, dynamic light scattering, water exchange rate. (PDF)

\section{AUTHOR INFORMATION}

\section{Corresponding Authors}

*E-mail: caravan@nmr.mgh.harvard.edu. (P.C.) 
*E-mail: iki@m.tohoku.ac.jp. (N.I.)

\section{Author Contributions}

The manuscript was written through contributions of all authors. All authors have given approval to the final version of the manuscript.

\section{Funding}

No competing financial interests have been declared. This work was supported in part by Award No. R01EB009062 from the National Institute for Biomedical Imaging and Bioengineering and the National Center for Research Resources for instrumentation (Grant Nos. S10OD010650, S10RR023385, and P41RR14075). E.B. thanks the Swiss National Science Foundation (advanced postdoc mobility fellowship) as well as the NIH (K99HL125728) for support. N.I. thanks JSPS for KAKENHI (Grant No. 25288061).

\section{Notes}

The authors declare no competing financial interest.

\section{REFERENCES}

(1) Helm, L.; Merbach, A. The Chemistry of Contrast Agents in Medical Magnetic Resonance Imaging, 2nd ed.; Wiley, 2013; pp 25-81.

(2) Boros, E.; Gale, E. M.; Caravan, P. Dalton Trans. 2015, 44, 48044818.

(3) Caravan, P.; Ellison, J. J.; McMurry, T. J.; Lauffer, R. B. Chem. Rev. 1999, 99, 2293-2352.

(4) Bonnet, C. S.; Tóth, É. Adv. Inorg. Chem. 2016, 68, 43-96.

(5) Helm, L.; Merbach, A. E. Chem. Rev. 2005, 105, 1923-1960.

(6) Dumas, S.; Jacques, V.; Sun, W.-C.; Troughton, J. S.; Welch, J. T.; Chasse, J. M.; Schmitt-Willich, H.; Caravan, P. Invest. Radiol. 2010, 45 $600-612$.

(7) Caravan, P.; Farrar, C. T.; Frullano, L.; Uppal, R. Contrast Media Mol. Imaging 2009, 4, 89-100.

(8) Zhang, S.; Merritt, M.; Woessner, D. E.; Lenkinski, R. E.; Sherry, A. D. Acc. Chem. Res. 2003, 36, 783-790.

(9) Aime, S.; Delli Castelli, D.; Terreno, E. Angew. Chem., Int. Ed. 2005, 44, 5513-5515.

(10) Soesbe, T. C.; Merritt, M. E.; Green, K. N.; Rojas-Quijano, F. A.; Sherry, A. D. Magn. Reson. Med. 2011, 66, 1697-1703.

(11) Iki, N.; Tanaka, T.; Hoshino, H. Inorg. Chim. Acta 2013, 397, $42-47$.

(12) Tanaka, T.; Iki, N.; Kajiwara, T.; Yamashita, M.; Hoshino, H. J. Inclusion Phenom. Mol. Recognit. Chem. 2009, 64, 379-383.

(13) Iki, N.; Hiro-oka, S.; Nakamura, M.; Tanaka, T.; Hoshino, H.

Eur. J. Inorg. Chem. 2012, 2012, 3541-3545.

(14) Baranyai, Z.; Pálinkás, Z.; Uggeri, F.; Maiocchi, A.; Aime, S.; Brücher, E. Chem. - Eur. J. 2012, 18, 16426-16435.

(15) Sarka, L.; Burai, L.; Király, R.; Zékány, L.; Brücher, E. J. Inorg. Biochem. 2002, 91, 320-326.

(16) Laurent, S.; Elst, L. V.; Muller, R. N. Contrast Media Mol. Imaging 2006, 1, 128-137.

(17) Caravan, P.; Cloutier, N. J.; Greenfield, M. T.; McDermid, S. A.; Dunham, S. U.; Bulte, J. W. M.; Amedio, J. C.; Looby, R. J.; Supkowski, R. M.; Horrocks, W. D.; McMurry, T. J.; Lauffer, R. B. J. Am. Chem. Soc. 2002, 124, 3152-3162.

(18) Zhou, X.; Caravan, P.; Clarkson, R.; Westlund, P.-O. J. Magn. Reson. 2004, 167, 147-160.

(19) Laurent, S.; Vander Elst, L.; Copoix, F.; Muller, R. N. Invest. Radiol. 2001, 36, 115-122.

(20) Horrocks, W. D. W.; Sudnick, D. R. J. Am. Chem. Soc. 1979, 101, 334-340, DOI: $10.1021 /$ ja00496a010.

(21) Beeby, A.; Clarkson, I. M.; Dickins, R. S.; Faulkner, S.; Parker, D.; Royle, L.; de Sousa, A. S.; Williams, J. A. G.; Woods, M. J. Chem. Soc., Perkin Trans. 2 1999, 2, 493-503.

(22) Swift, T.; Connick, R. E. J. Chem. Phys. 1962, 37, 307-320.

(23) Micskei, K.; Helm, L.; Brucher, E.; Merbach, A. E. Inorg. Chem. 1993, 32, 3844-3850.
(24) Dellavia, I.; Helm, L.; Merbach, A. E. Inorg. Chem. 1992, 31, 2230-2233.

(25) Southwood-Jones, R. V.; Earl, W. L.; Newman, K. E.; Merbach, A. E. J. Chem. Phys. 1980, 73, 5909-5918.

(26) Zhang, S.; Wu, K.; Sherry, A. D.; Inves. Invest. Radiol. 2001, 36, $82-86$.

(27) Powell, D. H.; Dhubhghaill, O. M. N.; Pubanz, D.; Helm, L.; Lebedev, Y. S.; Schlaepfer, W.; Merbach, A. E. J. Am. Chem. Soc. 1996, $118,9333-9346$.

(28) Gianolio, E.; Cabella, C.; Colombo Serra, S.; Valbusa, G.; Arena, F.; Maiocchi, A.; Miragoli, L.; Tedoldi, F.; Uggeri, F.; Visigalli, M. JBIC, J. Biol. Inorg. Chem. 2014, 19, 1-12.

(29) Moriggi, L.; Yaseen, M. A.; Helm, L.; Caravan, P. Chem. - Eur. J. 2012, 18, 3675-3686.

(30) Tóth, É.; Helm, L.; Merbach, A. E.; Hedinger, R.; Hegetschweiler, K.; Jánossy, A. Inorg. Chem. 1998, 37, 4104-4113.

(31) Aime, S.; Carrera, C.; Delli Castelli, D.; Geninatti Crich, S.; Terreno, E. Angew. Chem., Int. Ed. 2005, 44, 1813-1815. 